\title{
Biology of Shortfin Mako Shark (Isurus oxyrinchus Rafinesque, 1810) from the Eastern Mediterranean
}

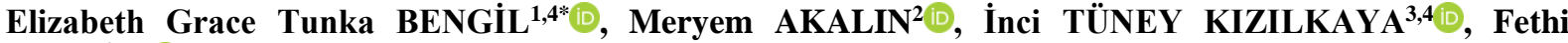 \\ BENGIL ${ }^{1}$ (1)
}

${ }^{1}$ Girne American University, Marine School, Girne, TRNC via Turkey

${ }^{2}$ Ege University, Faculty of Fisheries, Department of Fisheries Biology 35100, Bornova, Izmir, Turkey

${ }^{3}$ Ege University, Faculty of Science, Department of Biology, 35100, Bornova, Izmir, Turkey

${ }^{4}$ Mediterranean Conservation Society, Kazımdirik Mah. No:8 Folkart Time 1. Blok Kat:8 No: 807 Bornova, Izmir, Turkey

*Corresponding author: elizabetheronat@gau.edu.tr

Received 28 March 2019; Accepted 21 June 2019; Release date 15 December 2019.

How to Cite: Bengil, E. G. T., Akalın, M., Tüney Kızılkaya, İ., \& Bengil, F. (2019). Biology of Shortfin Mako Shark (Isurus oxyrinchus Rafinesque, 1810) from the Eastern Mediterranean Acta Aquatica Turcica, 15(4), 425-432 https://doi.org/10.22392/actaquatr.545997

\begin{abstract}
Shortfin mako, Isurus oxyrinchus Rafinesque, 1810, is one of the commercially and recreationally important shark species in the world. Still knowledge on its biology and status is limited in the eastern Mediterranean. Three individuals were caught from Turkish waters. Two individuals (one female and one male) stomach contents, morphological measurements and female' gonad histology were studied. According to the results from macroscopic examination and gonad histology, the female was a Stage 1-immature, and smallest female ever recorded from Turkish waters. In addition, phylogenetic network of mitochondrial haplotypes was constructed for all three individuals. The phylogenetic network analysis supported that the species having a metapopulation as mentioned in previous studies. Since every information is critical for development of conservation actions aiming endangered species, we believe that our study will contribute to the limited knowledge on $I$. oxyrinchus biology and reproduction habits in Eastern Mediterranean
\end{abstract}

Key words: Isurus oxyrinchus, conservation biology, ecology, Eastern Mediterranean.

\section{Doğu Akdeniz'den Kısa Yüzgeçli Mako Köpekbalığının (Isurus oxyrinchus Rafinesque, 1810) Biyolojisi}

Özet

Kısa yüzgeçli mako köpekbalığı, Isurus oxyrinchus Rafinesque, 1810, dünyadaki ticari ve sportif açıdan önemli olan köpekbalığı türlerinden biridir. Türün, Doğu Akdeniz'deki biyolojisi ve durumu konusundaki bilgiler hala sinırlıdır. Çalışmada, Türkiye kıyılarından üç birey yakalanmıştır. Yakalanan iki bireyin (bir dişi ve bir erkek) morfolojik ölçümleri yapılmış, mide içeriği ve dişi gonad histolojisi incelenmiştir. Makroskopik inceleme ve gonad histolojisi sonuçlarına göre; dişi birey, aşama-1 (olgunlaşmamış) safhasında ve şimdiye kadar Türk sularından kaydedilen en küçük dişi bireydir. Ayrıca, her üç birey için filogenetik mitokondriyal haplotip ağ oluşturulmuştur. Yapılan bu filogenetik ağ analizi, önceki çalışmalarda belirtildiği gibi bir metapopülasyona sahip türlerin desteklendiğini göstermektedir. Her bilgi, nesli tükenmekte olan türlere yönelik koruma eylemlerinin geliştirilmesi için kritik öneme sahiptir. Çalışmamızın, Doğu Akdeniz'deki $I$. oxyrinchus biyolojisi ve üreme alışkanlıkları hakkındaki sınırlı bilgiye katkı yapacağına inanmaktayız.

Anahtar kelimeler: Isurus oxyrinchus, koruma biyoloji, ekoloji, Doğu Akdeniz

\section{INTRODUCTION}

Shortfin mako Isurus oxyrinchus Rafinesque, 1810 is an important target species, a bycatch in tuna and billfish longline and driftnet fisheries, particularly in high-seas fisheries, and is an important coastal recreational species around. 
Even though it is a target species in the world it has no commercial value in Turkish waters. The species is widely distributed in most tropical and temperate seas from $50^{\circ} \mathrm{N}$ (up to $60^{\circ} \mathrm{N}$ Eastern North Atlantic) to $50^{\circ} \mathrm{S}$. Eastern North Atlantic: occasional records from Norway (from about $60^{\circ}$ $\mathrm{N})$ and British Isles; more common further south, including Bay of Biscay, Spain, Portugal, the Azores, and off Northwest Africa, including the Mediterranean Sea. Western North Atlantic: Newfoundland, Canada, south along the Atlantic coast to Florida, U.S.A., and the Gulf of Mexico. It is a common, coastal to offshore, oceanic, epipelagic shark that occurs from the surface to at least $600 \mathrm{~m}$ deep. The species is viviparous with oophagy, but much of their reproductive cycle remains unknown. Litter size is between four and 25, with a gestation period of 15 to 18 months, followed by a resting period, making the overall time between birthing events as long as three years. Litter size increases with size of the female. Birth usually occurs in the spring and summer, but nursery grounds are poorly known other than they appear to be located close to coastal areas (Ebert and Stehmann, 2013). It is known that the species inhabits Turkish waters except the Black Sea (Bilecenoğlu et al., 2014) but is not a common species of Turkey's coasts (Kabasakal, 2015) or a common catch (Bengil and Başusta, 2018). There are some studies on their occurrence but there is no study on their biology besides their length-weight relationship in the eastern MediterraneanAim of this study is to obtain and report as much information as possible on a critically endangered IUCN redlist species (Malak, 2011), from two neonates (one female, one male) and one tissue sample, to contribute to its current state and future conservation status in the eastern Mediterranean.

\section{MATERIALS and METHODS}

Samples of three I. oxyrinchus were obtained, one being only a tissue sample two being whole individuals. First individual (Sample \#1) was caught by gillnet at $4 \mathrm{~m}$ in depth from Izmir Bay (Kırdeniz, Foça, Central Aegean Sea) on May 2015. The second individual (Sample \#2) was caught by longline from Gökova Bay (Akyaka, South Aegean Sea) on February 2016. Both individuals were dead before they were removed from the fishing gear and individual from Izmir Bay was freshly brought to the laboratory and other individual from Gökova Bay was preserved frozen by the fisherman till brought to the laboratory for further examinations. The third (Sample \#3) was obtained from Fethiye Bay May 2017 and was sent to the laboratory as a tissue sample. Before dissection of the whole individuals the length measurements were made by using a measuring board with a sensitivity of $1 \mathrm{~mm}$ and a digital caliper, weight measurements were made with an electronic scale with a sensitivity of $0.01 \mathrm{~g}$. The stomach contents were identified to the smallest taxon possible, recorded and weight with an electronic scale with a sensitivity of $0.001 \mathrm{~g}$. The whole individual's liver and total gonad weights were also recorded.

Tissue samples weighting $\pm 10 \mathrm{~g}$ were taken from ventral part of the individuals underneath the skin for the DNA barcoding of the species and were stored at $-20^{\circ} \mathrm{C}$ until the DNA extraction. Also, as part of the first project, from freshly brought individual, a part of the gonad was taken and preserved in $4 \%$ formaldehyde solution to examine the reproduction biology more detailed. Histological preparation procedures were conducted by first embedding the gonad part to a paraffin block, slicing the block to $6 \mu \mathrm{m}$ thickness and then staining with Mallory's hematoxylin and eosin. The slides were examined using a CX-31 phase contrast microscope and photographed with an Olympus DP-20 digital camera.

DNA isolation was performed with Tissue and Cell DNA Purification kit (GeneMark, Taiwan) according to manufacturer's instructions. DNA quality and quantity were measured with NanoDrop spectrophotometer (Nanodrop, Thermo Fisher Scientific, USA). All the DNAs were found suitable for PCR (Polymerase Chain Reaction) analysis after quality measurement. Cytochrome c oxidase subunit I (COI) gene ( 700 bp) was amplified by PCR analysis with primers LCO1490: 5'-GGT CAA CCAA ATC ATA AAG ATA TTG G-3' and HCO2198: 5'-TAA ACT TCA GGG TGA CCA AAA AAT CA-3' (Folmer et al., 1994). PCR reactions were performed in $25 \mu \mathrm{L}$ total volume of reaction buffer containing $2.5 \mathrm{mM}$ dNTPs (Thermo Scientific), $20 \mu \mathrm{M}$ of each primer, $0.4 \mu \mathrm{L}$ Dream Taq DNA polymerase, (Thermo Scientific), $10 \times$ Buffer, and $2 \mathrm{ng}$ template DNA. PCR analysis was performed by Biorad Thermal Cycler (USA). PCR conditions for both primer pairs were started with initial denaturation step at $95^{\circ} \mathrm{C}$ for 2 minutes, which was followed by 30 cycles of DNA denaturation at $95^{\circ} \mathrm{C}$ for 30 seconds, primer annealing for a min at $48^{\circ} \mathrm{C}$, DNA strand extension at 
$72^{\circ} \mathrm{C}$ for another $1 \mathrm{~min}$, and a final extension step at $72^{\circ} \mathrm{C}$ for $10 \mathrm{~min}$. The PCR products were separated on $1.5 \%$ agarose gel electrophoresis, stained with SafeView Stain (ABM) and visualized by image analyzer. Sequence analysis of PCR amplicons was performed at Ankara University Evolutionary Genetics Laboratory. Forward and reverse sequencing were performed, and results were edited in Sequencher 5.0.1 DNA sequence analysis software. Obtained sequences were compared to those from GenBank and BOLD systems using the BLAST algorithm. After sequence alignment Kimura 2-parameter (K2) model (Kimura, 1980) was found to be the most suited model for our data set and BIC and AICc results are given in Table 2. The sequences alignment, Neighbor Joining (NJ) and Maximum likelihood (ML) algorithm were done using MEGA 7 software (Kumar et al., 2015) and for the haplotype network analysis Network 5.0 were used (Polzin and Daneschmand, 2003) and was mapped using MapViewer 8.0.

Table 2. BIC and AICc values of the most suitable models

\begin{tabular}{lcccccccccc}
\hline \hline Model & K2+G & K2 & T92+G & JC+G & K2+G+I & HKY+G & T92 & JC & K2+I & HKY \\
\hline BIC & 4582.1 & 4585.3 & 4590.8 & 4592.1 & 4592.9 & 4593.9 & 4594.0 & 4595.2 & 4595.6 & 4597.3 \\
AICc & 2483.6 & 2495.8 & 2483.3 & 2502.6 & 2485.4 & 2468.4 & 2495.6 & 2514.7 & 2497.1 & 2480.8 \\
\hline
\end{tabular}

\section{RESULTS}

The morphometric measurements and their ratio to total length of the individuals are given in Table 1. The photos from anterior, dorsal, lateral and ventral of the individuals from Izmir Bay (female) and Gökova Bay (male), can be seen in Figure 1.

When stomach contents were examined, in female' stomach a piece of wood was found. The wood piece was measured to be $102 \mathrm{~mm}$ in length and $4.66 \mathrm{~g}$ in weight. In male individual's stomach, remains of a bony fish (Chlopsis bicolor Rafinesque, 1810), remains of two cephalopod, an isopod and a nematode were found, and weight of these prey items were measured to be $15.76 \mathrm{~g}, 130$ $\mathrm{g}, 0.37 \mathrm{~g}$ and $0.13 \mathrm{~g}$, respectively. Regarding histological examinations, since the male individual was preserved frozen by the fisherman until it was brought to the laboratory and histological investigations were only conducted on female individual. As macroscopically identified and verified histologically the individual was a "Stage 1-immature" according to ICES (2013) report (Figure 2).

Table 1. The measurements of the two individuals (F: female, M: male, LW: Liver weight, GW: gonad weight, TL: Total length, TW: Total weight, TrH: Trunk height, TrW: Trunk width, LJ: Lower jaw, UJ: Upper jaw).

\begin{tabular}{llllllll}
\hline \hline Measurements & Female & Male & Unit & Measurements & Female & Male & Unit \\
\hline LW & 115.86 & 426.5 & $\mathrm{~g}$ & 1st dorsal-fin height & 64 & 75 & $\mathrm{~mm}$ \\
GW & 17.87 & 46.22 & $\mathrm{~g}$ & 1st dorsal-fin length & 77 & 101 & $\mathrm{~mm}$ \\
TL & 7650 & 9430 & $\mathrm{~mm}$ & 2nd dorsal-fin base & 7 & 4 & $\mathrm{~mm}$ \\
TW & 2750 & 5980 & $\mathrm{~g}$ & 2nd dorsal-fin height & 8 & 5 & $\mathrm{~mm}$ \\
TrH & 103 & 128 & $\mathrm{~mm}$ & 2nd dorsal-fin length & 21 & 23 & $\mathrm{~mm}$ \\
TrW & 92 & 115 & $\mathrm{~mm}$ & Mouth length & 61 & 66 & $\mathrm{~mm}$ \\
Interdorsal space & 177 & 248 & $\mathrm{~mm}$ & Pre-mouth lenght & 54 & 70 & $\mathrm{~mm}$ \\
Internarial space & 36 & 31 & $\mathrm{~mm}$ & UJ 1st row teeth count & 22 & 21 & \\
Interorbital space & 52 & 71 & $\mathrm{~mm}$ & UJ 2nd row teeth count & 15 & 20 & \\
Interpectoral space & 80 & 75 & $\mathrm{~mm}$ & LJ 1st row teeth count & 21 & $4+4$ broken & \\
& & & & & & teeth & $13+2$ broken \\
Left eye height & 17 & 15 & $\mathrm{~mm}$ & LJ 2nd row teeth count & 22 & teeth & \\
Left eye length & 18 & 15 & $\mathrm{~mm}$ & LJ 3rd row teeth count & 8 & 2 & $\mathrm{~mm}$ \\
Right eye height & 16 & 15 & $\mathrm{~mm}$ & Anal-fin base & 9 & 3 & $\mathrm{~mm}$ \\
Right eye length & 17 & 16 & $\mathrm{~mm}$ & Anal-fin height & 12 & 5 & $\mathrm{~mm}$ \\
Preorbital length & 60 & 75 & $\mathrm{~mm}$ & Anal-fin length & 25 & 24 & $\mathrm{~mm}$ \\
Prenarial length & 41 & 45.9 & $\mathrm{~mm}$ & Anal opening caudal-fin & 130 & 81 & space \\
1st gill slit height & 64 & 55 & $\mathrm{~mm}$ & Pelvic-fin anal-fin space & 80 & 108 &
\end{tabular}




\begin{tabular}{cccclccc} 
2nd gill slit height & 54 & 60 & $\mathrm{~mm}$ & $\begin{array}{l}\text { Pectoral-fin pelvic-fin } \\
\text { space }\end{array}$ & 171 & 240 & $\mathrm{~mm}$ \\
3rd gill slit height & 49 & 60 & $\mathrm{~mm}$ & $\begin{array}{l}\text { Preventral caudal-fin } \\
\text { margin }\end{array}$ & 112 & 133 & $\mathrm{~mm}$ \\
4th gill slit height & 40 & 62 & $\mathrm{~mm}$ & $\begin{array}{l}\text { Upper postventral caudal- } \\
\text { fin margin }\end{array}$ & 115 & 186 & $\mathrm{~mm}$ \\
5th gill slit height & 46 & 62 & $\mathrm{~mm}$ & $\begin{array}{l}\text { Lower postventral caudal- } \\
\text { fin margin }\end{array}$ & 75 & 98 & $\mathrm{~mm}$ \\
1st dorsal-fin base & 63 & 83 & $\mathrm{~mm}$ & Dorsal caudal-fin margin & 157 & 186 & $\mathrm{~mm}$ \\
\hline \hline
\end{tabular}

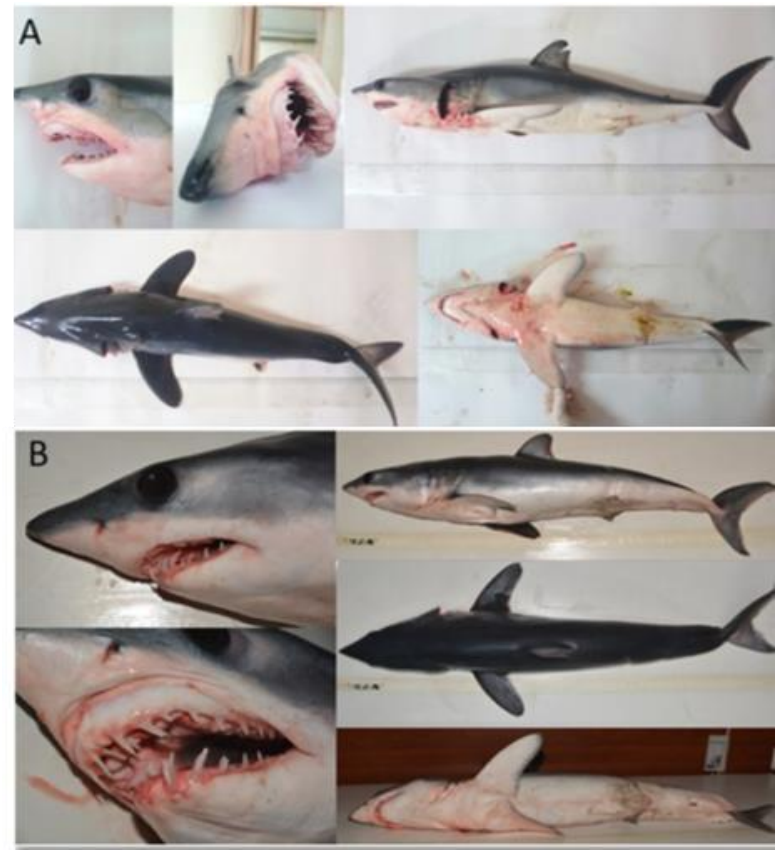

Figure 1. The photos of female (A) and male (B) individuals

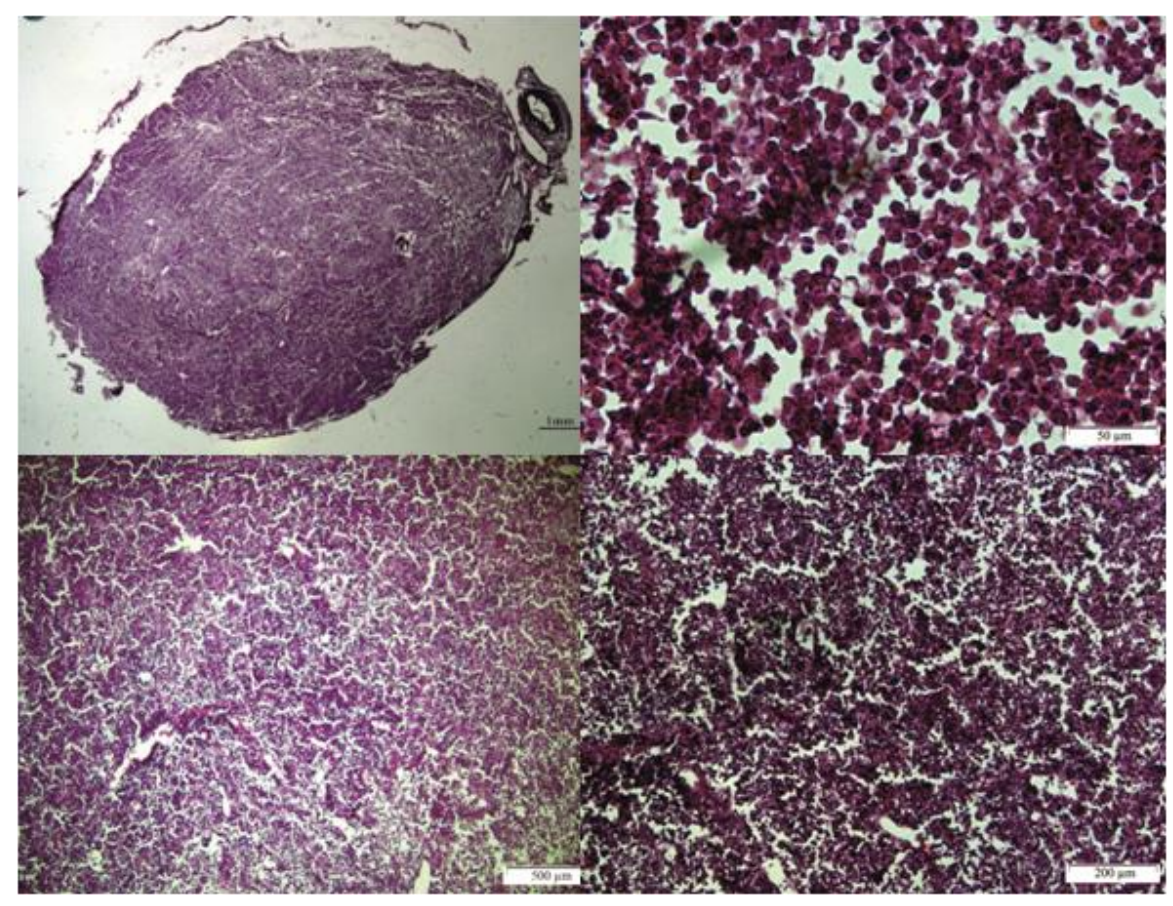

Figure 2. Ovarian follicle of I. oxyrinchus. 
The DNA samples extracted from each individual were identified as $I$. oxyrinchus, as the morphological identification suggested for the whole individuals. COI sequence of the Sample \#1 and Sample \#2 submitted GenBank with accession number KY290584 and MG214784, respectively. All the obtained sequences were compared with 116 other sequences from BOLD and GenBank systems. According to this model a Neighbor-Joining tree was prepared (Figure 3). Besides Neighbor-Joining tree, Network analysis was also conducted to identify the individual's origins as well as the relation between populations and 27 haplotypes were identified. All the individuals from this study was found to be from different haplotypes, and Sample \#2 and Sample \#3 weres found to be sharing the samehaplotype as the Sample \#1 (Figure 3, Figure 4). These results indicate that, $I$. oxyrinchus do not have geographical boundaries.

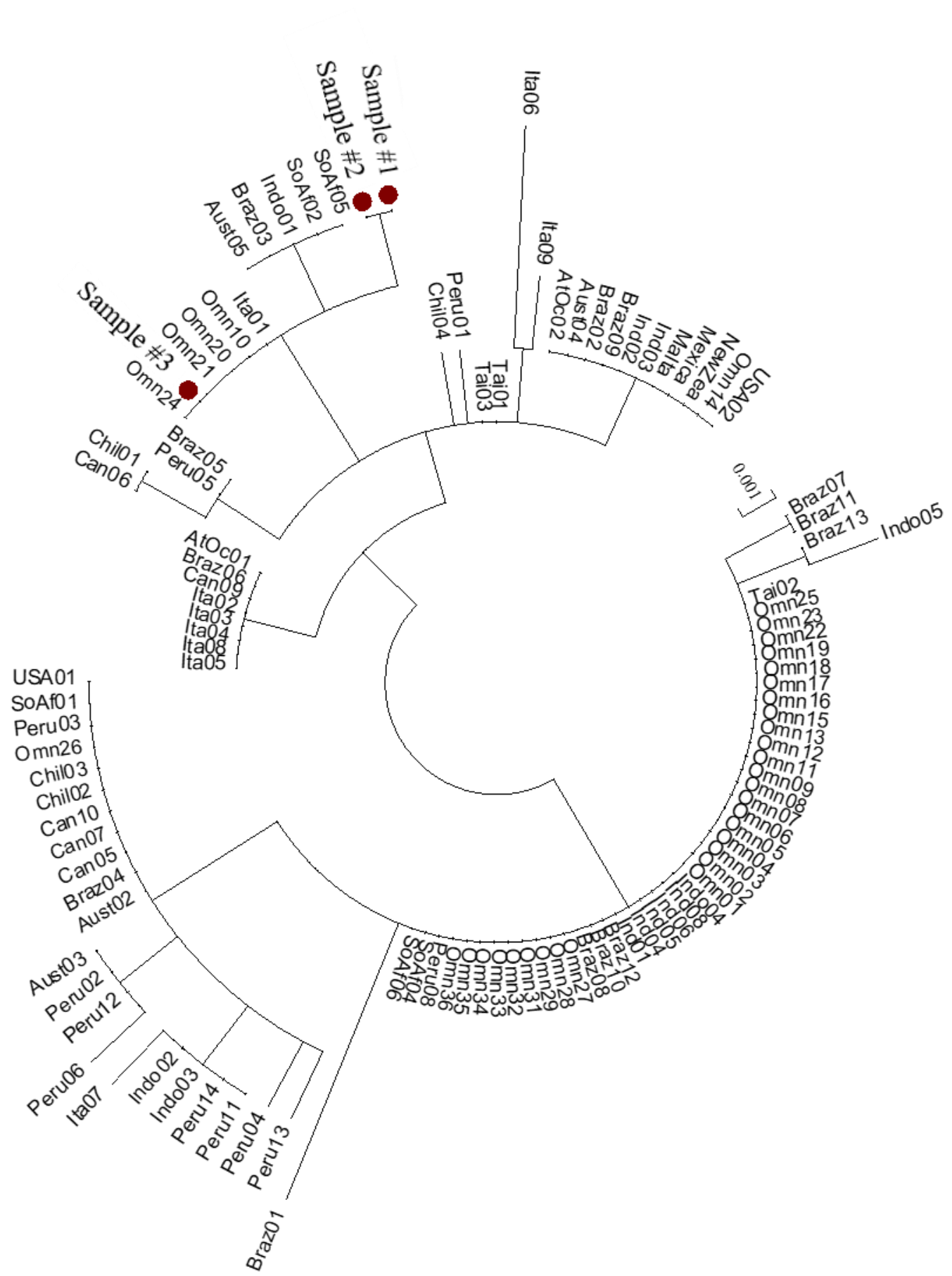

Figure 3. Neighbor-Joining tree made from the sequence existed with in BOLD and GenBank systems. The sequences from this study are shown in red (AUST: Australia; ATOC: Atlantic Ocean; BRAZ: Brazil; 
CAN: Canada; CHIL: Chili: IND: India; INDO: Indonesia; ITA: Italy, MALTA: Malta; MEXICA: Mexica; NEWZEA: New Zealand; OMN: Oman; PERU: Peru; SOAF: South Africa; TAI: Taiwan;

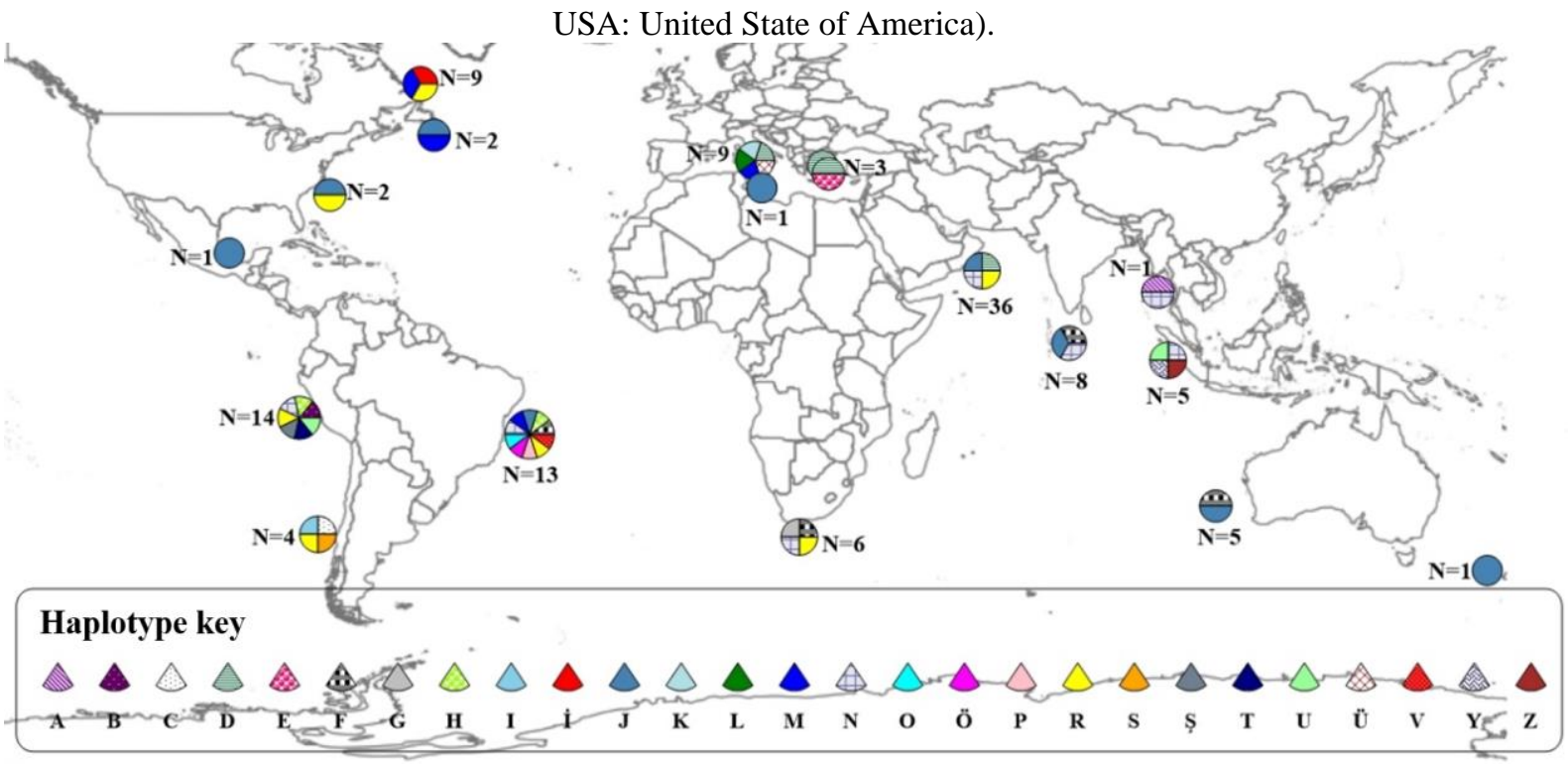

Figure 4. Number of used sequences from each countries $(\mathrm{N})$ and haplotypes network

\section{DISCUSSION}

Individual caught from Izmir Bay, Sample \#1, is the smallest reported female individual from Turkish coasts. Before this there was a report by Ergüden et al. (2013) on a male individual caught in 25 March 2010, with $69.8 \mathrm{~cm}$ TL and $2285 \mathrm{~g}$ total weight by a purse seine boat, from $54 \mathrm{~m}$ depth off the Samandag, coast of Iskenderun Bay. According to literature the parturition of I. oxyrinchus occurs during the spring, or summer and the pup's size at birth is between $60-70 \mathrm{~cm}$ (Gilmore, 1993). The both individuals reported in this study and Ergüden et al. (2013) being neonates suggests that the Mediterranean coast of Turkey is probably a new nursery ground for the mako shark since there were no reports historically.

Megalofonou et al. (2005) reported that, between 1998-2000, 321 mako sharks were caught as by-catch of tuna fisheries from the central and eastern Mediterranean. Among these individuals 313 were from the eastern Mediterranean and eight were caught from the central Mediterranean area and Levantine basin. Total and fork lengths of these individuals were recorded and reported, that most of these individuals were juveniles, with only a few large specimens from Levantine basin. These results also support the suggestion that I. oxyrinchus have either started or were already have been using Turkish coasts as breeding and nursery area but was not known. Another study done by Başusta (2016) reported neonate and juvenile individuals of species Heptranchias perlo, Squatina aculeata and Etmopterus spinax and point it out that northeastern Mediterranean was a mating, breeding and nursery area for some cartilaginous species. Histologically examined Sample \#1, the female, was a "Stage 1-immature" that corresponds with Conde-Moreno and Galvan-Magana, (2006) histological observations on ovarian follicle development conducted on I. oxyrinchus individuals from south-western coast of Baja California, Mexico. In case of the parturition period, a study conducted on 95 mature and 35 pregnant, in total 450 I. oxyrinchus individuals reported that species size-at-birth is around $70 \mathrm{~cm}$ and parturition occur late winter (end of February)-mid spring (Mollet et al., 2000) though supports similar parturition period, since the individual caught in February 2016 did not have scare of placenta suggests that parturition in eastern Mediterranean starts probably with the beginning of winter and continues till mid spring.

According to the Neighbor-Joining tree since Sample \#1 and Sample \#2 are on the same branch and Sample \#3 was sharing the same haplotype as Sample \#1, shows that, all individuals are related and from same origin. In addition, there were common haplotypes within the Mediterranean as well as Oman, supporting the concept of the species having a metapopulation as other studies conducted from other world seas suggests (Ward et al., 2008). 
Science base information is critical for development of conservation actions aimed at endangered species. Nevertheless, using lethal sampling methodologies unfortunately is the most effective way to do (Hammerschlag and Sulikowski, 2011), though there is a growing interest towards utilizing bycatch especially for large sharks such as shortfin mako. In conclusion, since, according to IUCN, $I$. oxyrinchus is Critically Endangered species (Walls and Soldo, 2016) it is important to know and continuously update its status as well as determine breeding areas all around the world with as little impact on its populations as possible. Especially in the Mediterranean whereas in 2014, $40 \%$ of cartilaginous fish species were threatened and in two years the numbers increased to more than half of Mediterranean chondrichthyans (Dulvy et al., 2014; Dulvy et al., 2016). With this rapid downfall of these species' existence it is of the essence to obtain and/or utilize data anyway we can collect and to distribute as much information as possible for their conservation.

Acknowledgements: This work was funded by The Rufford Foundation Grant numbers 17514-1 and 20115-2

\section{REFERENCES}

Başusta, N. (2016). New records of neonate and juvenile sharks (Heptranchias perlo, Squatina aculeata, Etmopterus spinax) from the North-eastern Mediterranean Sea, Marine Biodiversity, 46(2), 525-527, doi:10.1007/s12526-015-0391-z.

Bengil, E.G.T., \& Başusta, N. (2018). Chondrichthyan species as by-catch: A review on species inhabiting Turkish waters. Journal of the Black Sea/Mediterranean Environment, 24(3).

Bilecenoğlu, M., Kaya, M., Cihangir, B., \& Çiçek, E. (2014). An updated checklist of the marine fishes of Turkey. Turkish Journal of Zoology, 38(6), 901-929.

Conde-Moreno, M., \& Galvan-Magaña, F. (2006). Reproductive biology of the mako shark Isurus oxyrinchus on the south-western coast of Baja California, Mexico. Cybium, 30(4), 75-83.

Dulvy, N.K., Allen, D.J., Ralph, G.M., \& Walls, R.H.L. (2016). The conservation status of Sharks, Rays and Chimaeras in the Mediterranean Sea [Brochure]. IUCN, Malaga, Spain.

Dulvy, N.K., Fowler, S.L., Musick, J.A., Cavanagh, R.D., Kyne, P.M., Harrison, L.R., et al. (2014). Extinction risk and conservation of the world's sharks and rays. eLife, 3, doi: 10.7554/eLife.00590

Ebert D.A., \& Stehmann, M.F. (2013). Sharks, batoids and chimaeras of the North Atlantic. Food and Agriculture Organization of the United Nations.

Ergüden, D., Gürlek, M., \& Turan, C. (2013). A young Isurus oxyrinchus Rafinesque, 1810 (Chondrichthyes: Lamnidae) individual captured from Iskenderun Bay, Turkey. Mediterranean Marine Science, 14, 463480.

Folmer, O., Hoeh, W.R., Black, M.B., \& Vrjenhoek, R.C. (1994). Conserved primers for PCR amplification of mitochondrial DNA from different invertebrate phyla, Molecular Marine Biology and Biotechnology, 3, 294-299.

Gilmore, R.G. (1993). Reproductive biology of lamnoid sharks. Environmental Biology of Fishes, 38(1-3), 95114.

Hammerschlag, N., \& Sulikowski, J. (2011). Killing for conservation: the need for alternatives to lethal sampling of apex predatory sharks. Endangered Species Research, 14(2), 135-140.

ICES (2013). Report of the workshop on Sexual Maturity Staging of Elasmobranchs (WKMSEL), Lisbon, Portugal, $66 \mathrm{p}$.

Kabasakal, H. (2015). Occurrence of shortfin mako shark, Isurus oxyrinchus Rafinesque, 1810, off Turkey's coast. Marine Biodiversity Records, 8, e134.

Kimura, M. (1980). A simple method for estimating evolutionary rates of base substitutions through comparative studies of nucleotide sequences. Journal Molecular Evolution, 16,111-120.

Kumar, S., Stecher, G., \& Tamura, K. (2015). MEGA7: Molecular Evolutionary Genetics Analysis version 7.0. Molecular Biology and Evolution, 28, 27312739.

Megalofonou, P., Yannopoulos, C., Damalas, D., De Metrio, G., Deflorio, M., de la Serna, J.M., \& Macias D (2005). Incidental catch and estimated discards of pelagic sharks from the swordfish and tuna fisheries in the Mediterranean Sea. Fishery Bulletin, 103(4), 620-634.

Mollet, H.F., Cliff, G., Pratt Jr, H.L., \& Stevens, J. (2000). Reproductive biology of the female shortfin mako, Isurus oxyrinchus Rafinesque, 1810, with comments on the embryonic development of lamnoids. Fishery Bulletin, (2).

Polzin, T., \& Daneschmand, S.V. (2003). On Steiner trees and minimum spanning trees in hypergraphs. Operations Research Letters, 31,12-20

Walls, R.H.L., \& Soldo, A. (2016). Isurus oxyrinchus. The IUCN Red List of Threatened Species 2016: e.T39341A16527941. Downloaded on 30 September 2018. 
Ward, R.D., Costa, F.O., Holmes, B.H., \& Steinke, D. (2008). DNA barcoding of shared fish species from the North Atlantic and Australasia: minimal divergence for most taxa, but Zeus faber and Lepidopus caudatus each probably constitute two species. Aquatic Biology, 3(1), 71-78. 